Contents list available at IJRED website

Int. Journal of Renewable Energy Development (IJRED)

Journal homepage: www.ijred.com

\title{
VCO Production from Fresh Old Coconut Bunch by Circulating and Pumping Method
}

\author{
Muhamad Maulana Azimatun Nur*, Joko Mulyono, Danny Soetrisnanto
}

Center of Biomass and Renewable Energy, Chemical Engineering Department, Faculty of Engineering, Diponegoro University, Jl.Prof Sudharto,SH-Tembalang, Semarang INDONESIA

\section{Article history:}

Received December 15, 2011 Received in revised form Feb 3, 2012 Accepted February 12, 2012 Available online

\begin{abstract}
VCO (Virgin Coconut Oil) is one of coco-diesel source, made without high heating and chemicals. Commercial processes production, such fermentation and centrifugation usually need more time and expensive in cost and investment. Circulating by pumping through a nozzle is a new process method invented to produce VCO. The process followed by coalescence method, breaking emulsion by hitting particles through pipe and nozzle. The problem of this method was that the product gave lower yield than another method and not yet qualified. This research was purposed to discover correlation between pressure and time of circulation variables against yield and content (FFA, Peroxide, water content) represented by SNI (national Indonesian standard). Producing VCO initiated by producing coconut milk from fresh old coconut, then each 1 litre milk were pumped through the pipe and nozzle with variation of circulations pressures and time. The results were decanted for 10 hours so the oil and water would be separated. The oil at upper layer was taken as final product. Then the last step was analysed the oils and oil cake (blondo). The results showed that pressure and time of circulating variables gave impact to the yield. On optimum variables, 2 atm pressure and 15 minutes of circulating gave better results with $97 \%$ yield. This operating variables also affecting oil quality. The minimum water content is $0.1 \%$, free fatty acid is $0.18 \%$ and peroxide value is $2 \mathrm{mg} / \mathrm{kg}$ eq. The results showed that all of parameters meet the SNI standard.
\end{abstract}

Keywords: VCO, coalescence, emulsion

\section{Introduction}

Nowadays, coconut areal plantations in Indonesia are reached 3.8 million, produce 3.2 million ton as copra, whereas more than $90 \%$ are civil agricultural [1]. Plantation area spread out in Indonesia region, Sumatra has $33.63 \%$, Java has $22.75 \%$, Sulawesi has $19.40 \%$, Bali, NTB, and NTT have 7.70\%, Maluku, Papua $8.89 \%$ and Kalimantan have $7.26 \%$ [2].

Coconut could be potential for raw materials of cocodiesel/ coconut biodiesel. Coco-diesel/coconut biodiesel has higher oxygen content, compared with fossil diesel fuel. In addition, coconut oil processing to produce Coco-diesel/ coconut biodiesel is not complicated even be made with a very simple tool that can be produced by the people live in rural area and using their own coconuts plantation.

One of high potential and valuable product from coconut is VCO (Virgin Coconut Oil). The VCO as well can be used as coco-diesel source. In Indonesia, local farmer produce VCO in traditional method, which high FFA still remaining in the product and unstandardized by SNI (Indonesian codex standard product) [2].

VCO or virgin coconut oil is edible oil and fat produced without changing oil content, in mechanical method, no chemical addition, and low heating. VCO is produced from fresh old coconut bunch. The benefit of VCO produced by this way is pure, low FFA and peroxide, no colour and hard in rancidity [3].

The following research has been done by breaking

* Corresponding author: Tel: +62-24-7460058

E-mail: Muhamad_Maulana_Azim@yahoo.com 
emulsion with pumping and circulating method [4]. The method has low operation cost and needs short time. The research was purposed to determine circulating time, and decanting time variable against yield. The problem in this method is still high FFA content in product. It is needed to determine another variable to gain best qualified VCO.

Pressure is important variable in breaking emulsion by coalescence method [5]. Another following research was made to break emulsion in crude oil by steam jet pump and concluded good product [6]. The circulating method by breaking emulsion was used in crude oil industries [7], but the method has applied yet to produce VCO by breaking coconut emulsion.

This research was purposed to: (i) determine the correlation between pressure-time of circulation against yield and (ii) determine correlation between pressure-time against water content, FFA, and peroxide value.

\section{Method and Experiment Procedure}

The fresh old coconut bunch was collected from local farmer in Salatiga. The coconut was made into coconut cream by decantation for 3 hours. The machine was fabricated by centrifugal pump (stainless steel), pipes (PVC types) with two discharges, and first discharge for recycling, valve, manometer and tank (stainless steel).

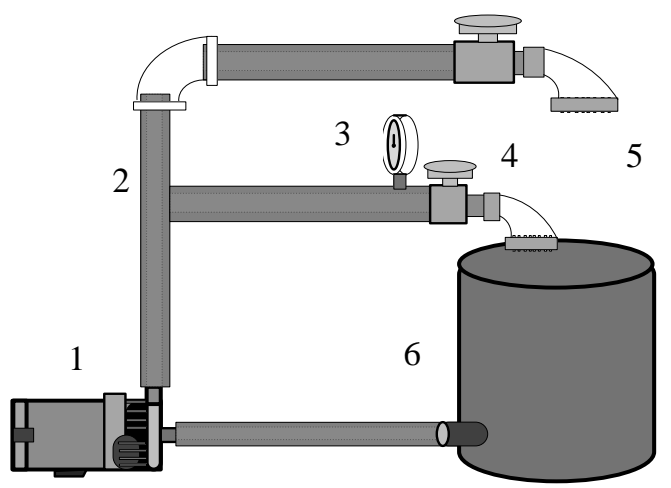

Fig. 1 Original design for operation: (1) centrifugal pump, (2) pipe, (3) manometer, (4) valve, (5) nozzle, and (6) container.

One litre coconut cream was pumped into machine, and then controlled by following circulating time variable: 5, 10, 15, and 20 minutes. Circulating pressure also vary from 1, 1.5, 2, 2.5 and $3 \mathrm{~atm}$. Cream emulsion was operated by pumping through inside pipe and discharged to nozzle. Dependent variable was 1 litre cream coconut, temperature $30^{\circ} \mathrm{C}$, and decanting time 10 hours.

The product was collected and decanted for 10 hours to gain separated 3 liquids: blondo (emulsifier oil cake), oil, and waste water. Oil was collected and measured by FFA, peroxide, and water content in VCO.

\section{Result and Discussion}

\subsection{Influence of pressure against yield at different time of circulation range.}

The research variables were 5, 10, 15, 20 minute and pressure $1 ; 1.5 ; 2 ; 2.5 ; 3$ atm. Experiment was stopped in range $3 \mathrm{~atm}$ and time of circulation 20 minute because yield percentage did not increase significantly, (the curve in graphic tend to flat. The explanation is oil contained in emulsion has limited and hard to be separated.

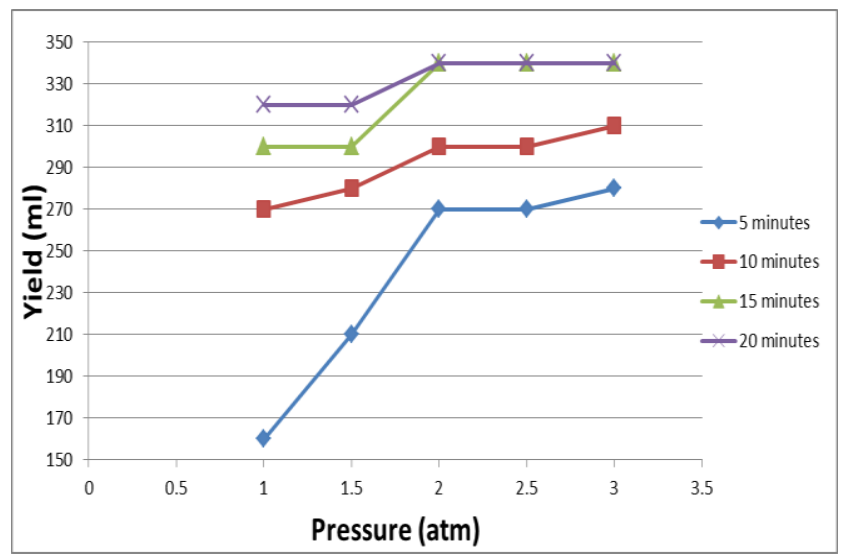

Fig. 2 Influences of pressure (x axis) against yield (y axis) in different time of circulation (curve range).

Coalescence between particles in emulsion has been done because most of particles formed larger particles (conjugated from similar little particle, it is possible that small particles parted from each other tend to have a small probability to coalescence. The optimum yield was $97 \%$, in optimum variable 2 atm and 15 minutes.

\subsection{Influence of pressure against yield at different time of circulation range.}

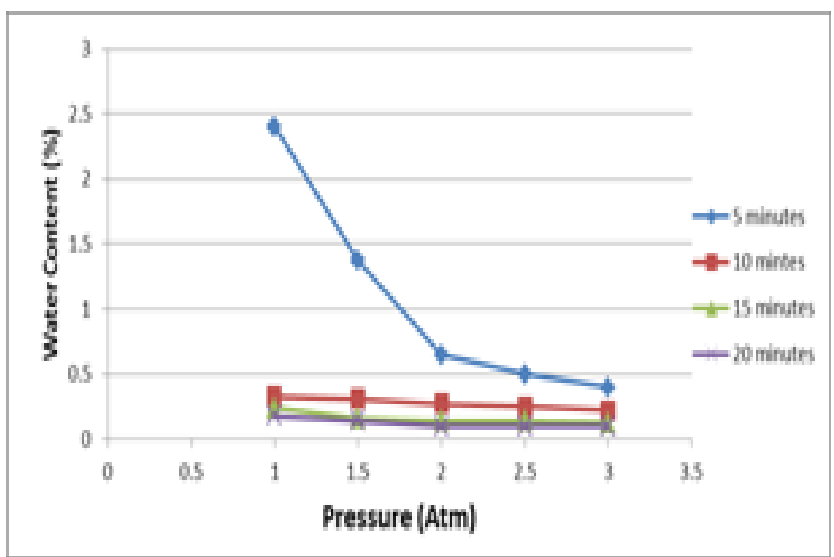

Fig. 3 Influences of pressure ( $\mathrm{x}$ axis) against water content (y axis) in VCO at different time of circulation (curve range) 
Water content has influenced free fatty acid forming reaction in oil content. The experiment has done by measuring water content against breaking emulsion based on circulation method. A water particle in emulsion has joined in same particles, forming larger particles.

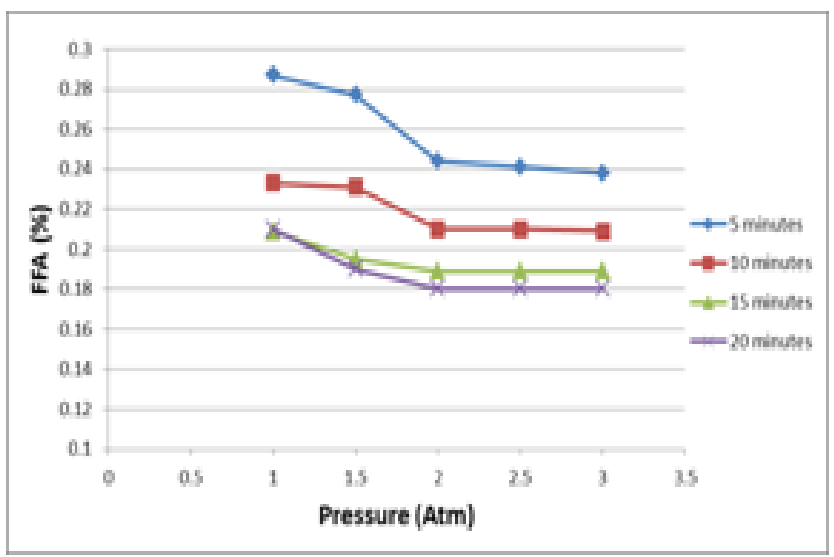

Fig. 4 Influences of pressure (x) against free fatty acid (y) at different time of circulation (curve range)

At same decanting time, the higher pressure variable, impacted in coalescence of the same particles. The oil has simple decanted from water. As SNI standard, water content allowance in VCO is $0.2 \%$. The result in this experiment was $0.1 \%$. The experiment indicates water content has qualified by SNI as time operation 20 minutes and $2 \mathrm{~atm}$ pressures.

Free fatty acid or FFA is used to determine rancidity in oil. This experiment indicates higher pressure-and time of circulation influenced in lowering FFA content. As SNI, maximum FFA allowance is $0.2 \%$. This experiment has FFA $0.18 \%$ in optimum variable $2 \mathrm{~atm}$ pressure and 20 minutes.

FFA is influenced by water content in oil, as reaction:

\section{Triglycerides + water $\rightarrow$ glycerol + fatty acid}

When the water content is removed from oil, influence in esterification reaction, free fatty acid has decrease. Rancidity in oil is important thing to keep quality and shelf life of the edible oil product. A qualified VCO has 2 years shelf life, caused by lower rancidity content.

Peroxide value is used to determine in oil quality and shelf life. Peroxide value has related in auto oxidation in oil. Auto oxidation is influenced by oil composition, mechanism in producing oil, temperature, oxygen dissolved in oil, bacteria, metal, and FFA [8].

In this experiment, lowering FFA also influenced in lowering peroxide value. When the pressure and time of circulation increased, water content in oil became lower, FFA in oil content became lower, and peroxide value became lower. FFA influences in oxygen diffusivity [8]. Free fatty acid can break top layer of oil and dissolving oxygen.
As SNI, peroxide value is $2 \mathrm{mg} / \mathrm{kg}$, this research has 2.7 $\mathrm{mg} / \mathrm{kg}$ at variable above 15 minute and $2 \mathrm{~atm}$. This value has not yet qualified by SNI. Supposed that contaminant as Aspergillus niger in equipment was not sterilized. It influences lipase enzyme from Niger has formed, and catalysed hydrolysis reaction. [1]. Therefore peroxide value of the oil higher than SNI criteria.

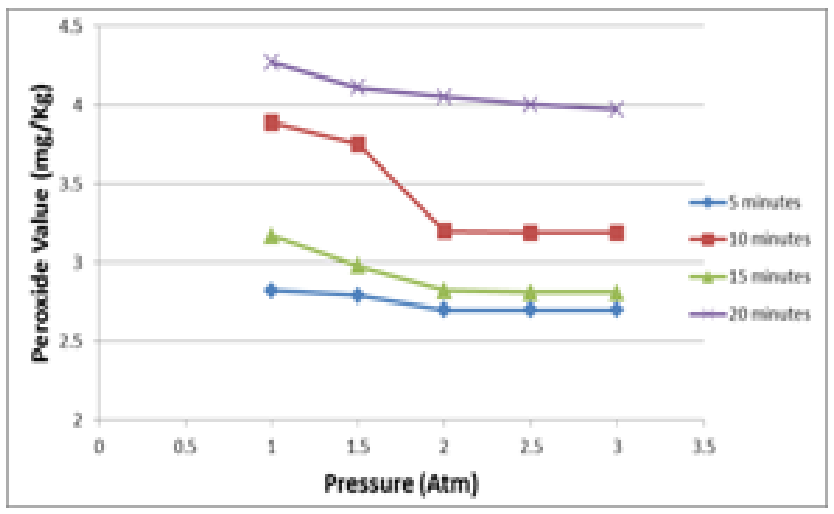

Fig. 5 Influences of pressure (x) against free fatty acid (y) at different time of circulation (curve range)

\section{Conclusion}

Circulation pressure and time influenced the yield and content of VCO. Higher pressure and longer of circulation time were resulting the increment of yield. Optimum variable in the operation is $2 \mathrm{~atm}$ and 20 minute of circulation time. Yield optimum is $97 \%$,

A higher pressure and longer of circulation time not only resulting the increment of yield, but also decreasing the water content, FFA, and peroxide value in oil. Optimum variable were $2 \mathrm{~atm}$ and 20 minute time of circulation. Water content is $0.1 \%$, FFA is $0.18 \%$ peroxide value is $2.75 \mathrm{mg} / \mathrm{kg}$.

\section{References}

[1] Onilude AA, Igbinadolor RO, Wakil SM (2010) Effect of Varying Relative Humidity on The Rancidity of Cashew (Anacardium occidentale L.) Kernel Oil by Lipolytic Organisms. African Journal of Biotechnology 9(31): 4890-4896.

[2] Allorerung D, Zainal M, Prastowo B (2008) Peluang Kelapa untuk Pengembangan Produk Kesehatan. Pengembangan Inovasi Pertanian 1(4): 298-315.

[3] Andi NA (2005) Virgin Coconut Oil. Minyak Penakluk Penyakit. PT AgroMedia.

[4] Hanik AN, Sheisarani E (2003) Pemecahan Emulsi pada pembuatan VCO dengan Proses Sirkulasi Pemompaan. Skripsi Sarjana S1, Teknik Kimia UNDIP, Semarang, Indonesia.

[5] Jung-Hyun R, Soo-Young N (2001) Break up Length of Conical Emulsion Sheet Discharged by Pressure-swirl Atomizer. International Journal of Automotive Technology 2(3): 103-107.

[6] Isamu F, Muneo Y, Yukihiro S (2001) Steam Jet Pump for Oil Recovery and Reformation. PARI (Port and Airport Research Institute) 3-1-1 Nagase, Yokosuka, Japan. pp: 239-826. 
Citation: Azimatun Nur M.M, Mulyono J, Soetrisnanto D, (2012) VCO Production from Fresh Old Coconut Bunch by Circulating and Pumping Method. Int. Journal of Renewable Energy Development 1: 28-31

[7] Anonim (2010) Ohsol Emulsion Breaking Process For Weathered Petroleum Lagoons. BriteWater Intl. 2600 South Shore Blvd Suite 300 League City, Texas 77573.
[8] Choe E, Min DB (2006) Mechanisms and Factors for Edible Oil Oxidation. Institute of Food Technologists 5. 